\title{
THE SOIL STERILANT AND NEMATICIDE GROUP
}

\begin{abstract}
$T$ HE first meeting of this Group was held at Rothamsted Experimental Station, Harpenden, on Tuesday, April 2. The twenty-six people who attended from all parts of the British Isles included nematologists, plant pathologists and chemists.

Dr. Peachey opened the meeting with a short introduction to the problems of using general soil biocides, especially in situations where the biological significance of factors affecting crop growth have not been fully assessed. $\mathrm{He}$ also reviewed the specific problems tackled by workers interested in soil sterilization in the British Isles.

In the informal discussion that followed, it was emphasized that crop responses could rarely be ascribed to the control of a specific pathogen. The analysis of responses to partial sterilization may be helped in future experiments by using biocides that are more specific than those in use at present. Improved growth after treatment has sometimes brought a hitherto unknown pathogen to notice, for example, Xiphinema diversicaudatum, a virus. carrying nematode. It was agreed that estimating control of pathogenic fungi was usually more difficult than measuring eelworm kill.
\end{abstract}

Most workers agreed that it was necessary to decrease the porosity of the surface layers of the soil after treatment by rolling, watering or sealing with polythene sheeting, to retain the fumigant gas long enough to kill pathogens. Little was known of the mode of action of these chemicals. Chemical soil sterilization was unlikely to be used much in arable farming unless it killed a whole range of pathogens able to damage crops grown in rotation in the years following treatment. Some existing compounds, for example methyl bromide, could be developed further.

Although chomicals acting specifically against nematodes or fungi may be produced, the Group predicted that the behaviour of some soil sterilants in controlling weeds and many different kinds of pests and pathogens may be too valuable to be discarded.

The Group decided that future meetings will be held to consider specific problems in the use of soil sterilants and that the next meeting, to be held at the Imperial College Field Station, Silwood Park, would be concerned with methods of application.

Further information concerning the Group can be obtained from Dr. J. E. Peachey, Rothamsted Experimental Station, Harpenden, Herts.

\section{PHOTOBIOLOGY IN BRITAIN}

\author{
By Prof. NORMAN MILLOTT \\ Bedford College, University of London
}

$\mathrm{T}$ HE importance of light in relation to life needs no emphasis. That the ultimate source of life energy is the Sun forms a trite slogan of the most elementary biology; other aspects of its importance as a sensory modality, and in the movements, colours and periodicitics of plants and animals, have all received attention in the past.

Unfortunately, however, the study of light and of life belongs to different traditional disciplinos in seience, so that only a fortunate few can handle both adequately. Others, realizing their one-sided competence, have turned aside from tempting and rewarding problems in frustration and despair, possibly with serious consequences to scientific progress. The labours of pioneers have attracted a following that is too small in proportion to thcir worth.

In recent years we have witnessed a remarkable revival of interest in photobiology in Britain and throughout the world. Though the scientist cynic might attribute the change to the fashion for 'fringes', it is perhaps no accident that the resurgence is contemporaneous with the rise to prominence of molecular biology and the renaissance of cytology.

The concept of excited electronic states, the realization that living matter traps excited electrons, putting their excess energy to good use, and the revelation of some critical stages in photosynthetic and visual systems have given impetus to those who would lay bare the route by which energy is transferred in living systoms. Their hope would be that, by this means, a glimpse may be obtained of the way in which living matter is pieced together at the molecular level.

The elaborate light optics at the disposal of the modern cytologist have given added importance to the study of light for biologists, and further, biologists now have at their disposal means of using, selectively, controlled radiation on structures within living cells.
This is an exciting scene to contemplate, but it is beset with pitfalls, so that progress will be surer if advancos are co-operative and if biologists, chemists and physicists can clasp hands firmly on the journey.

With such things in prospect, the British Photobiology Group was founded in 1955 on the initiative of Prof. J. A. V. Butler. Its first chairman was Dr. M. H. Pirenne and the secrotary was Dr. E. M. F. Roe.

The Group's object is to advance the study of photobiology and its applications by bringing together biologists, chemists and physicists to co-operate or to thrash out their problems, viewed from a variety of angles. Informality is the key-note, in the hope that in the free discussion and interchange of ideas, adherents of traditional disciplines will not only find at their disposal a pool of ideas and techniques, but also a means whereby traditional barriers may be lowered or even abolished.

The Group casts its net widely; membership is open to all those with a serious interest in tho effects of nonionizing radiation on living matter. Membership is not confined to those with purely fundamental or academic approaches, but includes members from institutions with interests as diverse as aviation, wool or soil research, dairying, fishcries, agricultural engineering, water pollution and scientific instrument design, as well as those engaged in phototherapy. Individuals with interests apparently so far apart as reaction kinetics, the culture of glass-house crops, the engineering aspects of light sources and the vitamins in milk, find in the Group a common forum.

The officers of the Group and the organizing committee are constituted to represent as many as possible of these aspects of photobiology. The present secretary is Dr. L. R. Fisher of the Fisheries Biochemical Unit at the National Institute for Research in Dairying, Shinfield, Berkshire, from whom further information can be ob- 